\title{
The spread of grapevine trunk diseases and improvement measures to limit their damage in conditions of the northern black sea region
}

\begin{abstract}
Sliusarenko O. ${ }^{1}$, Shmatkovska K. ${ }^{2}$
1I.I. Mechnikov Botanic garden of Odesa national university, Frantsuzkyi bulvar, 48/50, Odesa, 65058, Ukraine, ${ }^{2}$ NSC «V.E. Tairov Institute of viticulture and winemaking», 40-richcha Peremohy, 27, Tairovo,

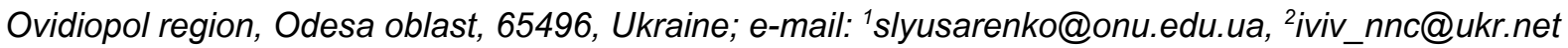

The purpose. To study spread of chronic illnesses of lumber of grape of fungal etiology on industrial plantings and to develop measures on limitation of injuriousness of causal organisms of diseases in conditions of Northern Black Sea Coast. Methods. Field and laboratory. Influence of diseases of lumber of grape on basic agrobiological indexes is probed: productivity, structure and quality of yield, economic efficiency of growing grape is also calculated. Influence of siliceous mineral (analcime) on spread of diseases and productivity of scrubs is probed. Results. By results of probes it was fixed that diseases of lumber of grape of fungal etiology (esca, eutiposis, black spot) on industrial plantings of Northern Black Sea Coast are spread everywhere. Spread of diseases of lumber of grape and their influence on productivity of scrubs lead to shortage of yield, reduce cost of gross harvest and profitableness of growing technical grades, and also increase net cost of production. It is determined that rooted supplementary feeding of scrubs of grape with analcime enables to suspend pathological process at esca disease, to reduce receptivity of plants to seasonal diseases and as result to augment productivity of scrubs and to increase product quality. It is shown that addition of base fungicides (Kvadris, Antrakol, Merpan, Shavit $\mathrm{F}$ and Ridomil Gold) into nutrient medium suppresses development of colonies and spores of causal organisms of eutiposis and black spot. Conclusions. Rooted supplementary feeding of plants with siliceous mineral slows down the pathological process called by esca, and diminishes receptivity of grades of grape to series of seasonal diseases.
\end{abstract}

Key words: grape, diseases of lumber, spread, development, injuriousness, rooted top-dressing, analcime, fungicides.

https://doi.org/10.31073/agrovisnyk201901-03

Introduction. The wine-growing zone of Ukraine is located on the verge of northern noncombustible industrial culture. The peculiarities of climate create favorable conditions for penetration, reproduction, preservation and spread of numerous pathogens of wood diseases grapes. The pathological process in diseases of perennial wood begins to develop after the damage of pathogens of the tissues of the conductive system, which leads to a gradual weakening of the plants, a decrease in their productivity, and in some cases - to their extinction [1-3].

Taking into account organotropic specialization of pathogens of diseases of the vascular system of plants, the most effective method should be the introduction of remedies in the zone of the root system, which, absorbing and moving with the current of water and nutrition elements on the vascular system will suppress the development of pathogens. Among such substances, scientific interest is represented by mobile silicon compounds that are capable of absorbing the root system and in tissue tissues of plants contribute to the strengthening of cell walls [4]. Besides, it was found that silicon nutrition contributes to increasing the resistance of plants not only to stress factors of biotic nature, but also to factors of abiotic nature [5-9].

It should be noted that in the field of viticulture measures to limit the harmfulness of chronic diseases of perennial wood mushroom etiology on the basis of reducing the susceptibility to plants are not sufficiently investigated. The application of grape-growing technology for receiving root nutrition of 
plants with silicon compounds in order to limit the development of pathogens in the vascular system diseases is, in our opinion, a new and relevant area of research.

The purpose. To clarify the distribution and development of wood diseases of grape mushroom etiology on industrial plantations and to improve measures to limit their harm in the conditions of the Northern Black Sea coast.

Materials and methods. Expeditionary surveys and record of damage to vineyards of business entities of various forms of ownership of Odessa, Nikolaev and Kherson regions were conducted during 2009-2013. According to the results of calculations, indicators of distribution and intensity of disease development were calculated.

In area of the Odessa black variety year of landing 2006, 2003, 2000, the influence of wood diseases on the basic agrobiological indicators: yield, structure and quality of the crop was investigated and the economic efficiency of growing of grapes was calculated.

The study of the influence of the silicon-containing mineral (analcim) on the spread of diseases, the productivity of the bushes and the economic efficiency of growing grapes were carried out during 2011-2013 on the plantations of the Odessa black variety year of landing 2006.

During 2011-2012 in the laboratory of the NSC "Institute of Viticulture and Wine-making named after V.E. Tairov" studied the parameters of the development of Eutypa armeniacae Hansf et Carter and Phomopsis viticola Sacc. an artificial agar medium and a toxicological evaluation of fungicides with respect to these pathogens was carried out.

Results. It is established that on the grape plantations of the Northern Black Sea coast the most widespread diseases of perennial wood are: esca, eutipios and black spot. The spread of the esca on the areas under investigation increased during the vegetation and at the end it was $3 \%-13 \%$, depending on the age of the plantings and the characteristics of the varieties (Table 1).

The distribution of eutipios increased on average from $6 \%$ to $15 \%$, respectively, in vineyards in 2006 and 2000 years of planting. On plantations with relatively young plants, there were symptoms of an initial stage of development of the disease, which, with an increase in the age of plants, progressed to the stage of dying diseased plants.

The defeat of plants by esca triggers in a chronic course of the disease causes secondary signs of manifestation on the leaves, which affects the productivity of grape plantations. Thus, with an increase in the indexes of damage, there was a decrease in yields of 1,3-1,7 times.

The defeat of grapes by the causative agent of eutipios causes morphological and physiological changes that manifest themselves in reducing the growth volume of annual shoots, the number of inflorescences and the average mass of clusters. The result of such changes is a reduction in productivity of 1,6-2,4 times, depending on the intensity of the damage.

Prior to the beginning of the growing season, the germination spores of the pathogen of black spotting appeared on the annual shoots, but during the vegetation the spread of the disease on the green organs of plants did not exceed $10 \%$. On plants with signs of damage by black spotting, the inhibition of the dilatation of the cells is observed. During the growing season, the pathogen develops on young leaves and shoots, causing a decrease in the area of the assimilation surface and the average length of the shoots. It was noted [10] that the greatest harm of black spots occurs during a long spring period with a background of high humidity. 
Table 1 - Distribution and development of diseases of perennial wood in the vineyards of the Northern Black Sea Coast (averaged over 2009-2011).

\begin{tabular}{|c|c|c|c|c|c|c|c|c|c|}
\hline & Variant & \multirow{2}{*}{\multicolumn{2}{|c|}{$\begin{array}{c}\text { Esca } \\
\text { III decade } \\
\text { of August }\end{array}$}} & \multicolumn{2}{|c|}{ Eutipios } & \multicolumn{4}{|c|}{ Black spot } \\
\hline \multirow[t]{2}{*}{$\begin{array}{l}\text { year of } \\
\text { planting }\end{array}$} & \multirow[t]{2}{*}{ variety } & & & \multicolumn{2}{|c|}{$\begin{array}{l}\text { Ill decade } \\
\text { of August }\end{array}$} & \multicolumn{2}{|c|}{$\begin{array}{l}\text { before the } \\
\text { beginning of } \\
\text { the vegetation }\end{array}$} & \multicolumn{2}{|c|}{$\begin{array}{l}\text { the end of } \\
\text { the growing } \\
\text { season }\end{array}$} \\
\hline & & $P$ & $R$ & $P$ & $R$ & $P$ & $R$ & $P$ & $R$ \\
\hline \multicolumn{10}{|c|}{ DP"DG Tayrovskoye" } \\
\hline \multirow[t]{3}{*}{2006} & Odessa black & 4,7 & 1,1 & 7,5 & 2,6 & $\begin{array}{l}62, \\
3\end{array}$ & $\begin{array}{l}12, \\
5\end{array}$ & 5,2 & 1,0 \\
\hline & Sukholiman White & 3,6 & 0,8 & 7,4 & 2,4 & $\begin{array}{l}61, \\
0\end{array}$ & $\begin{array}{l}12, \\
2\end{array}$ & 4,7 & 0,9 \\
\hline & Muscat Odessa & 3,3 & 0,8 & 7,6 & 2,5 & $\begin{array}{l}59, \\
2\end{array}$ & $\begin{array}{l}11, \\
9\end{array}$ & 4,3 & 0,8 \\
\hline \multirow[t]{3}{*}{2003} & Odessa black & 7,8 & 1,9 & $\begin{array}{c}10 \\
5\end{array}$ & 3,6 & $\begin{array}{l}82, \\
5\end{array}$ & $\begin{array}{l}16, \\
7\end{array}$ & 8,0 & 1,9 \\
\hline & Pigeon & 6,7 & 1,5 & 9,7 & 3,4 & $\begin{array}{l}80, \\
2\end{array}$ & $\begin{array}{l}16, \\
2\end{array}$ & 7,3 & 1,6 \\
\hline & Golden early & 3,5 & 0,7 & $\begin{array}{l}14, \\
4\end{array}$ & 5,2 & $\begin{array}{l}81, \\
5\end{array}$ & $\begin{array}{l}16, \\
3\end{array}$ & 6,7 & 1,3 \\
\hline \multirow[t]{3}{*}{2000} & Odessa black & 11,9 & 2,7 & $\begin{array}{l}14, \\
1\end{array}$ & 4,6 & $\begin{array}{l}89, \\
0\end{array}$ & $\begin{array}{l}18, \\
1\end{array}$ & $\begin{array}{l}11, \\
7\end{array}$ & 2,5 \\
\hline & Cabernet Sauvignon & 12,5 & 3,0 & $\begin{array}{c}16 \\
7\end{array}$ & 5,5 & $\begin{array}{l}84, \\
7\end{array}$ & $\begin{array}{l}17, \\
1\end{array}$ & $\begin{array}{l}11, \\
4\end{array}$ & 2,4 \\
\hline & Muscat Odessa & 7,9 & 1,8 & $\begin{array}{l}13, \\
8\end{array}$ & 4,8 & $\begin{array}{l}87, \\
3\end{array}$ & $\begin{array}{l}17, \\
6\end{array}$ & $\begin{array}{l}10, \\
4\end{array}$ & 2,3 \\
\hline \multicolumn{10}{|c|}{ OS "Koblevo" } \\
\hline 2006 & Riesling Rhine & 3,6 & 0,8 & 8,0 & $\begin{array}{l}2, \\
7\end{array}$ & $\begin{array}{l}58, \\
3\end{array}$ & $\begin{array}{l}11, \\
7^{11}\end{array}$ & 4,8 & 0,9 \\
\hline 2003 & Chardone & 3,7 & 0,7 & 8,8 & $\begin{array}{l}3, \\
0\end{array}$ & $\begin{array}{l}64, \\
0\end{array}$ & $\begin{array}{l}12, \\
8\end{array}$ & 5,9 & 1,0 \\
\hline \multirow[t]{3}{*}{2000} & Odessa black & 5,1 & 1,2 & 7,7 & $\begin{array}{l}2, \\
8\end{array}$ & $\begin{array}{l}67, \\
4\end{array}$ & $\begin{array}{l}13, \\
5\end{array}$ & 6,3 & 1,5 \\
\hline & Cabernet Sauvignon & 6,6 & 1,7 & $\begin{array}{l}11, \\
7^{1}\end{array}$ & $2^{4,}$ & $\begin{array}{l}65, \\
9\end{array}$ & $2^{13,}$ & 7,3 & 1,4 \\
\hline & Merlo & 5,4 & 1,3 & $\begin{array}{l}10, \\
5\end{array}$ & $\begin{array}{l}3, \\
5\end{array}$ & $\begin{array}{l}63, \\
9\end{array}$ & $\begin{array}{l}12, \\
8\end{array}$ & 6,3 & 1,1 \\
\hline \multicolumn{10}{|c|}{ AF farm "Belozersky" } \\
\hline 2006 & Chardone & 6,1 & 1,2 & $\begin{array}{l}10, \\
4\end{array}$ & $\begin{array}{l}3, \\
5\end{array}$ & $\begin{array}{l}66, \\
1\end{array}$ & $\begin{array}{l}13, \\
2\end{array}$ & $\begin{array}{l}10, \\
4\end{array}$ & 1,9 \\
\hline 2003 & Riesling Rhine & 5,5 & 1,1 & $\begin{array}{l}13, \\
8\end{array}$ & $\begin{array}{l}4, \\
6\end{array}$ & $\begin{array}{l}73, \\
4\end{array}$ & $\begin{array}{l}14, \\
7\end{array}$ & $\begin{array}{l}10, \\
1\end{array}$ & 1,9 \\
\hline 2000 & Sukholiman White & 5,6 & 1,1 & $\begin{array}{l}16, \\
8\end{array}$ & $\begin{array}{l}5, \\
1\end{array}$ & $\begin{array}{l}79, \\
4\end{array}$ & $\begin{array}{l}15, \\
9\end{array}$ & 9,3 & 1,5 \\
\hline
\end{tabular}

Note: $P$ - spread of disease (\%); $R$ - development of disease (\%) 
The conducted researches have shown, that damage of grape plantings by the agents of wood diseases affects productivity and causes lack of harvest from 0,6-0,8 $t$ / ha to 1,3-1,4 $t$ / ha, depending on age of plantings and hydrothermal conditions of the year.

The use recommended for use on industrial grapes, fungicides does not give the desired results, as evidenced by the development and spread of diseases in industrial plants (Table 1). We conducted in our laboratory toxicological evaluation of the recommended drugs confirmed their high activity inhibition of the development of pathogens eutipios and black spot (Fig. 1). This fact needs to be clarified to change the rules of the use of fungicides.
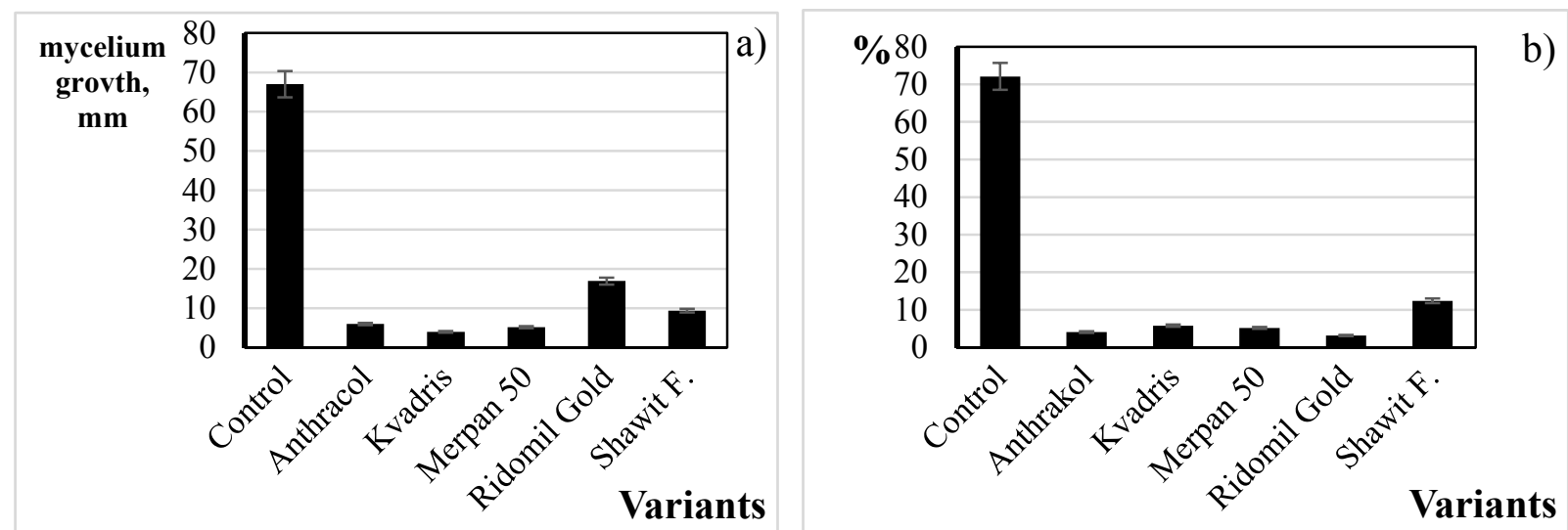

Fig. 1. Influence of fungicides on growth of mycelium Eutypa lata Tul. \& C. Tul. (a) and germination of the spores of Phomopsis viticola Sacc. (b) (NSC "IViV named after V. E. Tairov", 2011-12).

Taking into account the peculiarities of the organotropic specialization of pathogens of perennial wood diseases and the role of silicon in plant nutrition [11], it was assumed that the reception of root nutrition of plants with silicon containing minerals will increase the resistance of plants to biotic and abiotic stress factors, which will contribute to inhibition of the pathological process and increase the efficiency of the use of chemical agents protection.

For the silicon fertilization of the experimental plants of the Odessa black variety, we selected the minerals analcim - from the group of water zeolites, a class of silicates (water aluminosilicate) containing $40-45 \%$ of mobile silicon and more than 30 biogenic elements in an available form for the plant.

The obtained data indicate that the introduction of silicon-containing mineral into the zone of the root system of grapes hinders the development of the skeletons and the intensity of the damage to plantations decreases from $3,1-3,6 \%$ (control) to $0,9-1,8 \%$ (analcim). Suspends the development of seasonal diseases mildew, oidium, white and gray rot. It is likely that this explains the positive effect of nutrient uptake by the silicon mineral on the productivity of plants and the quality of the crop (Table 2).

Table 2 - Influence of root cropping of vine shrubs with analcim on productivity and quality indices of Odesa Black (SE "DG" Tairovske ", 2013)

\begin{tabular}{|l|c|c|c|c|c|}
\hline Variant & $\begin{array}{c}\text { Number of } \\
\text { bunches per 1 } \\
\text { medium bush, } \\
\text { pcs. }\end{array}$ & $\begin{array}{c}\text { Average } \\
\text { mass of } \\
\text { bunches, } \mathrm{g}\end{array}$ & $\begin{array}{c}\text { Harvest of 1 } \\
\text { bush, kg }\end{array}$ & $\begin{array}{c}\text { Mass portion 100 } \\
\mathrm{cm}^{3} \text { sugar in the } \\
\text { juice of berries, g }\end{array}$ & $\begin{array}{c}\text { Mass concentration } \\
\text { of titrated acids in 1 } \\
\mathrm{dm}^{3}, \mathrm{~g}\end{array}$ \\
\hline Analcim & 29,7 & 184 & 5,4 & 18,6 & 7,2 \\
\hline Control & 29,5 & 170 & 5,0 & 17,8 & 6,4 \\
\hline $\mathrm{Sx}_{\mathrm{SSD}}$ & & 1,6 & 1,2 & - & - \\
\hline
\end{tabular}




\section{Conclusions}

1. An analysis of the phytosanitary condition of the industrial grape stands of the Northern Black Sea region indicates that the diseases of the grape wood (esca, eutopios and black spot) are widespread and their development becomes epiphytotic significance. The maximum manifestation of the disease occurs in unfavorable conditions for the plants in the environment (frost damage and drought).

2. Lack of crop due to plant damage to wood diseases is 6,2 to $14,6 \%$, depending on the degree of damage and the age of plantings.

3. The root nutrition of grapes with a silicon-containing mineral suspends the pathological process of esophageal disease, and increases the resistance of plants to seasonal diseases, which leads to an increase in planting productivity and product quality improvement.

4. The high efficiency of fungicides (Kvadris, Antrakol, Merpan, Shavit F and Ridomil Gold) has been experimentally confirmed for the development of pathogens of eutopios and black spots, which suggests that it is recommended to be used in the early weeks of the year against the pathogen of black spots.

\section{Bibliography}

1. Apruda P. I. Vynohradna loza. Zakhyst vid khvorob i shkidnykiv . P. I. Apruda. - Kyshyniv 2006. $-31 \mathrm{~s}$.

2. Shkidnyky, khvoroby i bur'yany na vynohradnykakh . [ZH. A. Chychynadze, N. A. Yakushyna, A. S. Skorikov y dr.] - K .: «Ahrarna nauka». - 1995. - $304 \mathrm{~s}$.

3. Zakhyst vynohradnykh nasadzhen' vid khvorob i shkidnykiv: Praktychnyy posibnyk . [V. V. Vlasov, M. S. Konstantynova, E. A. Shmatkovskaya y dr.]. — Odesa: NNTS «IViV im. V. YE. Tayirova ». 2014. - 66s.

4. Havrylov V. A. Zastosuvannya kurvularina i anal'tsyma u vyrobnytstvi koshty z funhitsydnoyu deystvieem, kompozytsiya i sposib yiyi otrymannya (varianty). V. A. Havrylov, N. V. Zaimenko, A. N. Slyusarenko. Patent WO 2013105909 A1 .

5. Rahmatullah A. F. Effect of silicon application on wheat (Triticum aestivum L.) growth under water deficiency stress . F. A. Rahmatullah, T. Aziz, M. Maqsood et all. Emir. J. Food Agric. — 2007, № 19 (2). - P. 1-7.

6. Hamayun M. Silicon alleviates the adverse effects of salnity and drought stress on growth and endogenous plant growth hormones of soybean (Glycine max L.) . M. Hamayun, E. Sohn, S. Kha et all. .. Pak. J. Bot. - 2010, № 42 (3). - P. 1713-1722.

7. Sacała E. Rola krzemu w odporności roślin na stress wodny . E. Sacała .. J. Elementol. — 2009. № 14 (3). - P. 619-630.

8. Fauteux F. Silicon and plant desease resistance against pathogenic fungi . [F. Fauteux, W. RémusBorel, R. Menzies, J. Bélanger] .. FEMS Microbiology Letters. — 2005, № 249. — P. 1-6.

9. Epstein E. Silicon: its manifold roles in plants .. Ann. Appl. Biol. - 2009 Vol. 155. - p. 155-160.

10. Shruft H. Zakhyst roslyn u vynohradarstvi . H. Shruft, Khanns-Khaynts Kassemayer per z nim. YU. M. Stroykov. — Frayburh, 2010. - $108 \mathrm{~s}$.

11. Liang Y. Silicon in agriculture . M. Nikolic, R. Bèlanger, H. Gong, A. Song. - Springer Science + Business Media Media Dordrecht, 2015 — 235 p. 